\title{
THE ROLES OF HOUSEWIFES IN INFORMAL SECTOR (STUDY ON PRODUCTION OF BATU KAPUR IN DESA MANGKUNG LOMBOK TENGAH)
}

\author{
Rohimi \\ Pascasarjana, UIN Sunan Kalijaga, dinobastian11@gmail.com
}

\begin{tabular}{l|l|l} 
Diterima: 4 Februari 2019 & Direvisi :25 April 2019 & Diterbitkan: 30 Juni 2019
\end{tabular}

\begin{abstract}
This study was examined the role of women as the housewives in Mangkung Village who work as laborers in the process of producing limestone. It used qualitative methods to collect data like interviens, observation, and documentation. The purpose of this research was to find out how were the role of women who works with men in limestone production work. The results of this study proved that the women strongly participate in the work of limestone production processes with men, even the work of women in limestone production was more dominant than the male laborers. And what is the role of women who have become housewives who take part and participate in and work together and collaborate with men in the same scope of work, namely in the process of producing limestone. And the motivating factors for working as limestone production laborers are (a) weak family economy, (b) preserving cultural work, and (c) weak insight and knowledge. While the obstacles faced by bousewives as laborers in the production of limestone. First, physical constraints such as the severity of the work done in the production of limestone, such as destroying limestone after burning, raising and lowering lime when going to marketing, even they use safety devices such as masks and gloves to maintain their safety and physical bealth when work. Second, the constraints on his position as a housewife who must prioritize their primary work in the house such as preparing the needs of their busbands and children. Do not arrive at the existence of work outside the house as a laborer of lime production and forget about his responsibilities as a wife.
\end{abstract}

Keywords: The role of housewives, the informal sector, and the production of limestone.

\begin{abstract}
Abstrak
Dalam penelitian mengkaji tentang peran yang dilakukan oleh perempuan yang sudah menjadi seorang ibu rumah tangga di Desa Mangkung yang bekerja sebagai buruh dalam proses produksi batu kapur. Penelitian ini menggunakan metode kualitatif dengan menggunakan langkah-langkah pengumpulan data seperti wawancara, observasi, dan dokumentasi. Tujuan dari penlitian ini, untuk mengetahui bagaimana peran perempuan yang sudah menjadi seorang ibu rumah tangga yang bekerjasama dengan kaum laki-laki pada pekerjaan produksi batu kapur. Dan Hasil dalam penelitian ini seperti mereka yang sudah menjadi seorang ibu rumah tangga, akan tetapi sangat berpartisipasi dalam pekerjaan proses produksi batu kapur dengan laki-laki, bahkan pekerjaan kaum perempuan pada produksi batu kapur lebih dominan dari pada pekerjaan buruh laki-laki walaupun sedikit ringan. Dan bagaimana peran kaum perempuan yang sudah menjadi seorang ibu rumah tangga yang ikut andil dan berpartisipasi dan bekerja sama dan kolaborasi dengan laki-laki pada lingkup pekerjaan yang sama yakni pada proses produksi batu kapur. Dan faktor pendorong mereka bekerja sebagai buruh produksi batu kapur yakni (a) lemahnya ekonomi keluarga, (b) melestarikan pekerjaan budaya, dan (c) lemahnya wawasan dan pengetahuan. Sedangkan kendala yang dihadapi ibu rumah tangga sebagai buruh dalam produksi batu kapur. Pertama, kendala secara fisik seperti beratnya pekerjaan yang dilakukan pada produksi batu kapur, seperti merubuhkan batu kapur setelah pembakaran, menaikkan dan menurunkan kapur saat pergi pemasaran, bahkan sampai mereka menggunakan alat pengaman seperti masker, dan sarung tangan untuk menjaga
\end{abstract}


keselamatan dan kesehatan fisik mereka saat bekerja. Kedua, kendala terhadap posisinya sebagai seorang ibu rumah tangga yang harus mengedepankan pekerjaan primernya di dalam rumah seperti mempersiapkan kebutuhan suami dan anaknya. Jangan sampai dengan eksistensinya dalam pekerjaan diluar rumah sebagai buruh produksi kapur dan lupa akan tanggung jawbanya sebagai seorang istri.

Kata Kunci: Peran ibu rumah tangga, sektor informal, dan produksi batu kapur.

\section{Latar Belakang}

Berbicara tentang eksistensi kaum perempuan dalam pekerjaan di sektor informl, tentu hal itu menjadi langkah dalam membentuk pemberdayaan terhadap perempuan, dan pemberdayaan tersebut yang selalu diperkenalkan dalam konteks perempuan dalam pembangunan atau Women in Development (WID). Pendekatan ini bertujuan untuk memberikan peluang sebesar-besarnya bagi kaum perempuan untuk ikut dalam partisipasi pembangunan dan kesejahteraan. ${ }^{1}$ Karena kaum perempuan juga memiliki hak untuk membantu tercapainya suatu kesejahteraan, agar tidak selamanya kaum perempuan dianggap sebelah mata atas eksistensi kaum laki-laki. Oleh karena itu tindakan kaum perempuan pada saat sekarang ini, berbeda dengan zaman dahulu dimana pada zaman dahulu perempuan hanya boleh bekerja di rumah saja, karena pada zaman saat ini keterlibatan dan keberhasilan gerakan emansipasi perempuan cukup melebar pada pekerjaan di luar rumah dan sering terlibat dalam berbagai kegiatan-kegiatan produksi seperti pekerjaan yang dilakukan oleh laki-laki. ${ }^{2}$

Begitu juga yang terjadi pada masyarakat di Desa Mangkung, di mana banyak perempuan yang sudah menjadi seorang ibu rumah tangga yang bekerja sebagai

${ }^{1}$ M. Arnas Firdiansyah R, "Pengaruh Motivasi Bekerja Perempuan Di Sektor Informal Terhadap Pembagian Kerja Dan Pengambilan Keputusan Dalam Keluarga," Skripsi Institut Pertanian Bogor, 2009.

2 Ninin Ramadani, "Implikasi Peran Ganda

Perempuan Dalam Kehidupan Keluarga Dan Lingkungan Masyarakat," Sosietas Vol. 6 No. 2 (September 2016). buruh produksi batu kapur. Seperti penjelasan di atas terkait bagaiamana pembangunan itu terjadi karena partisipasi masyarakat yang mampu untuk mengolah sumber daya alam sebagai wadah dalam menuangkan potensi mereka, dan mampu menciptakan tercapai konsep pembangunan tersebut. Misalnya masyarakat yang ada di Desa Mangkung, mereka mengolah hasil alam seperti batu gunung yang di produksi menjadi batu kapur yang memiliki kegunaan sebagai bahan bangunan. ${ }^{3}$ Oleh karena itu, potensi sumber daya manusia tentu akan menjadi alat untuk membantu terciptanya kondisi masyarakat atau sosial yang lebih baik. Misalnya di dalam tulisan ini yang secara eksplisit membahas tentang tindakan atau perjuangan kaum perempuan yang sudah menjadi seorang ibu rumah tangga yang terus berpartisipasi dalam membentuk kesetaraan dan relasi dengan kaum laki-laki, dan juga mampu untuk membantu kondisi sejahtera seperti mampu untuk mendapatkan uang dari hasil sebagai buruh kapur dalam membantu ekonomi keluaganya. Karena dengan adanya persepsi, misalnya perempuan itu sangat disubordinat oleh kaum laki-laki, akan tetapi bentuk kesetaraan dan relasi yang terjadi antara kaum laki-laki dan perempuan itu sudah banyak terjadi seperti didalam sosial, budaya, dan politik. Akan tetapi, yang terjadi di Desa Mangkung, para perempuan membangun sebuah kesetaraan dan relasi dengan kaum lakilaki dengan mampu menciptakan kolaborasi dan partisipasi dalam satu lingkup pekerjaan yang dilakukanya seperti sama-sama menjadi

3Observasi 22 Maret 2017. 
seorang buruh dalam proses produksi batu kapur.

Eksistensi kaum perempuan di lingkup sektor informal itu tidak lagi menjadi sesuatu yang asing kita dengar. Karena aktivitas perempuan dalam lingkup pekerjaan sektor informal sudah dikembangkan sejak lama, misalnya pada fenomena kaum perempuan yang menjadi buruh pada produksi bagtu kapur di Desa Mangkung, itu sudah menjadi pekerjaan yang turun-temurun dari nenek moyang, sehingga dari hasil observasi peneliti dengan salah seorang pemiliki tungku, ekisistensi produksi batu kapur sudah ada sejak zaman jepang, dan tentu dengan eksistensinya yang sudah begitu lama tidak mungkin hanya dilakukan oleh laki-laki, bahkan sistematis yang menempatkan satu buruh laki-laki dan empat buruh perempuan itu sudah dilakukan sejak dulu. Oleh karena itu tindakan kaum perempuan pada sektor informal dikarenakan oleh beberapa faktor misalnya pada masyarajat Mangkung itu dipengaruhi oleh budaya dan adat istiadat seperti menjalankan pekerjaan yang telah lahir dari nenek moyangnya.

Eksistensitas kaum perempuan pada pasrtisipasi pekerjaan selalu disentuh dengan hanya sebagai orang dengan pekerjaan domestik (homemaker) yang dinilai tidak dapat berkontribusi secara aktif di luar rumah, sehingga itu yang menjadi pengaruh perannya tidak lebih dari sekadar aktivitas didalam rumah. Perempuan selalu disimbolisasikan dengan kata, "sumur, dapur, kasur" namun pada masa dewasa ini yang harus digugat eksistensinya. Persepsi tersebut hanya dinilai sebagai sebuah persepsi yang tidak dapat dibuktikan dengan ril, karena pada dasarnya pada masa dewasa ini banyak perempuan yang juga mengambil bagian penting diranah produktif, entah itu mereka sudah menjadi seorang ibu rumah tangga atau belum. ${ }^{4}$

${ }^{4}$ Darmin Tuwu, "Peran Pekerja Perempuan Dalam Memenuhi Ekonomi Keluarga: Dari Peran Domestik Menuju Sektor Publik," Jurnal Al Irzah: Jurnal
Oleh karena itu, Kenyataannya terhadap eksistensitas kaum perempuan terhadap sektor informal, ini tidak menutup keinginan para perempuan untuk berkecipung didalam pekerjaan sektor tersebut, karena dengan tujuan untuk menghidupi perekonomian rumah tangganya. Sektor informal begitu identik pada sektor perekonomian yang dijalankan oleh orang dengan tingkat ekonomi rendah, sehingga pekerjaan perempuan yang banyak ditemukan di sektor ini banyak yang bertumpu pada sektor pertanian yang kemudian dikembangkan pada sektor lain seperti berdagang, bertani, berladang, sektor produksi, dan lain sebagainya. ${ }^{5}$

Dalam bekerja dengan memberikan kesempatan penuh di luar rumah, tentu itu akan menjadi kegelisahan para perempuan yang menjadi ibu rumah tangga, dan pemilik pekerjaan yang primer dalam internal keluarga. Karena menggabungkan pekerjaan dalam mengurus anak dengan pekerjaan di luar rumah merupakan faktor dalam meletakkan batasan peran intraktif kaum perempuan dan menjadi sangat disparitas dibandingkan dengan kaum laki-laki. ${ }^{6}$

Pada dewasa ini keterlibatan kaum perempuan yang berperan pada sektor produktif sepertinya bukan hal baru untuk diperbincangkan. Karena peran dalam tindakan pekerjaan produktif adalah peran yang dilakukan oleh seseorang, entah itu laki-laki maupun perempuan, karena memang pada pekerjaan produktif itu sangat menyangkut pekerjaan yang menghasilkan barang dan jasa, baik untuk dikonsumsi maupun untuk diperdagangkan. ${ }^{7}$ Karena pada zaman saat ini,

Hasil-Hasil Penelitian-ISSN: $1978-9726$ (p); 2541-0717 (e)

Volume 13, Nomor 1 (Mei 2018),. 64.

${ }^{5}$ Ibid.

${ }^{6}$ Julia Cleves Mosse, Gender \& Pembangunan (Yogyakarta: Rifka Annisa Women's Crisis Center, 2018),. 40.

7 Firdiansyah R, "Pengaruh Motivasi Bekerja Perempuan Di Sektor Informal Terhadap Pembagian 
eksistensi seorang ibu rumah tangga dituntut untuk berpotensi, kreatif, sabar, dan tekun dalam membantu tercapainya kesejahteraan keluarga. Banyak hal yang telah dilakukan ibu rumah tangga sebagai peranti untuk mendapatkan ekonomi dalam membantu kesejahteraan keluarga dengan bekerja pada sektor-sektor imformal seperti berwirausaha, buruh produksi, menjadi kuli kasar bahkan sampai harus mengerjakan pekerjaan yang biasa dilakukan oleh laki-laki. ${ }^{8}$ Oleh karena itu, dalam partisipasi para perempuan di Desa Mangkung menjadi ibu rumah tangga yang memiliki peran ganda. Dimana peran primernya adalah mengurus pekerjaan rumah, dan peran skundernya bekerja di ranah produksi batu kapur. Dan produksi batu kapur merupakan pekerjaan yang dilakukan untuk bertujuan semata-mata membantu ekonomi keluargnya juga melestarikan pekerhjaan budaya. Akan tetapi, ini menjadi prihatin dan kemirisan para stakeholders dalam pemberdayaan dan perubahan. Karena dalam pekerjaan batu kapur, merupakan pekerjaan yang tak semudah pekerjaan yang lain, karena harus angkat berat dan lain-lain. Oleh karena itu, mereka sebagai ibu rumah tangga yang tidak akan meyerah dengan menggali ekonomi atau pendapatan yang tak seberapa besar melalui pekerjaan yang berat seperti proses produksi batu kapur tersebut.

Mereka menjadi ibu rumah tangga yang begitu tegar dalam menjalankan aktivitasnya diranah pekerjaan informal selain menjadi ibu rumah tangga yang semestinya hanya mengerjakan pekerjaan domestik. Namun dalam fenomena ini, akan sedikit disparitas dengan ibu rumah tangga yang lainnya yang hanya bekerja dalam menjual sayur, mencari kayu bakar, dan berdagang. Karena dari hasil

Kerja Dan Pengambilan Keputusan Dalam Keluarga,", 9.

${ }^{8}$ Eka Pariyanti, "Peran Ibu Rumah Tangga Dalam Meningkatkan Pendapatan Keluarga," Jurnal DIN AMIKA Vol. 3 No. 2 (Desember 2017). observasi peneliti sampai 60an perempuan yang bekerja menjadi buruh dalam proses produksi batu kapur, dan mereka semua sudah menjadi seorang ibu rumah tangga dengan usianya yang sudah cukup tua. Sehingga itu sangat menarik untuk dikaji menjadi sebuah tulisan. Ketika dijumpai dengan fenomenologi yang melahirkan prihatin akan eksistensi ibu rumah tangga dengan usia yang begitu tua, akan tetapi masih berpartisipasi dalam aktivitas kesehariannya, dengan menjalankan pekerjaan sektor informal sebagai buruh produksi batu kapur, dengan bekerja seharian dan dengan tiga jam istirahat, bahkan mereka sudah menjadi seorang ibu rumah tanggapun bekerja dengan partisipasi kolaborasi dengan kaukm laki-laki.

\section{Metode}

Penelitian merupakan cara untuk melakukan observasi dan penggalian kajian terhadap permasalahan yang telah direncanakan oleh peneliti. Oleh karena itu penelitian berasal dari bahasa inggris (research) yang artinya pencarian dan penyelidikan terhadap suatu pristiwa untuk menjawab suatu permasalahan. Dan tujuan dari penelitian untuk menguji teori dan membantu teori dalam lingkup penelitian alamiah atau ilmiah yang dilakukan dengan tindakan praktis. ${ }^{10}$ Untuk melihat sutau persoalan yang ada didalam masyarakat, maka manusia harus menggunakan cara observasi dan penelitian, karena problem dalam masyarakat itulah yang disebut dengan fakta sosial. Oleh karena itu penelitian merupakan sebuah cara untuk mengkaji suatu problem sosial yang di sebut dengan fakta sosial. ${ }^{11}$ Setiap peneliti melakukan cara untuk mengumpulkan data dan informasi dari

9 Wawancara pemilik tungku di Desa Mangkung, 22 Maret 2017.

${ }^{10}$ Elvinaro Ardianto, Metodologi Penelitian Untuk. Publike Relations Kuantitatif Dan Kualitatif ( (Bandung: Simbiosa Media, 2010).

${ }^{11}$ Herman Arisandi, Buku Pintar Tokob-Tokoh Sosiologi Dari Klasik Sampai Modern (Yogyakarta: IRCiSoD, 2015),. 53-54. 
responden untuk menjawab suatu permasalahan yang telah direncanakan sebelumnya.

Dalam penelitian ini, peneliti menggunakan metode kualitatif. Dan Penelitian ini berlokasi di Desa Mangkung Kecamatan Praya Barat Kabupaten Lombok Tengan. Karena disanalah peneliti melihat fenomena yang sangat menarik untuk dikaji yaitu terkait dengan beberapa perempuan yang sudah menjadi seorang ibu rumah tangga yang bekerja sebagai buruh dalam proses produksi batu kapur. Metode pengumpulan data dalam penelitian ini melalui metode wawancara, observasi, dan dokumentasi. Dengan tujuan untuk mendapatkan data yang valid. Dan responden dalam penelitian ini baik secara primer maupun skunder yakni para buruh kapur perempuan yang sudah menjadi seorang ibu rumah tangga. Dan responden kedua yakni pemilik tungku yang ada di Desa Mangkung Kecamatan Prata Barat Kabupaten Lombok Tengah.

\section{Gambaran Tentang Ibu Rumah Tangga Sebagai Buruh Dalam Produksi Batu Kapur}

Dari hasil observasi peneliti, ini tentu menjadi hal yang tak lazim dalam kacamata sosial. Dimana, para perempuan yang sudah menjadi ibu rumah tangga rela bekerja dengan waktu yang begitu cukup dalam meninggalkan pekerjaan utamanya sebagai ibu rumah tangga yang seharusnya mengurus pekerjaan rumah, mengasuh anak, mencuci pakaian, memasak, dan lain sebagainya. Akan tetapi di Desa Mangkung merupakan dimana proses produksi batu kapur menjadi tempat berkecipungnya para ibu rumah tangga yang memerankan peran gandanya, yang dimana seharusnya sebagai ibu rumah tangga harus lebih inten dalam pekerjaan internal keluarga. Akan tetapi mereka lebih menghabiskan waktu di luar rumah dalam mengerjakan produksi batu kapur dengan sebagai seorang buruh.
Karena banyak penelitian atas fenomena para ibu-ibu rumah tangga dalam sektor informal, Seperti ibu rumah tangga dalam dalam buruh cuci, ibu rumah tangga dalam produksi pertanian, dan ibu rumah tangga dalam pekerjaan sekotr informal dengan menjadi pedagang sayur-sayuran. Akan tetapi fenomena sosial yang terjadi di Desa Mangkung akan menjadi perhatian yang tidak kalah untuk diprihatinkan, dan juga sedikit ada kemirisan atas fenomena ini. Karena banyak ibu rumah tangga yang bekerja di sektor informal seperti yang saya jelaskan di atas. Akan tetapi diranah produksi batu kapur cukup menghantam kesehatan fisik bagi mereka dan tentu memberikan tantangan bagi perempuan sebagai ibu rumah tangga.

Dari hasil wawancara peneliti dengan Bapak Mulyadi sebagai salah satu pemilik tungku ${ }^{12}$ di Desa Mangkung. Dari pemaparan Bapak Mulyadi, bahwa jumlah tungku di Desa Mangkung berjumlah 70an tungku atau tempat pembakaran batu, dan buruh perempuan yang menjadi buruh dalam produksi batu kapur di Desa Mangkung lebih dari 60an buruh perempuan bahkan lebih. Dalam pekerjaan batu kapur bahwasannya waktu buruh bekerja mulai dari jam 7:00 pagi sampai jam 5:00 sore dengan waktu istirahat $3 \mathrm{jam}$. Dan artinya disini peran ibu rumah tangga dalam melakukan partisifasinya di sektor informal dalam produksi batu kapur cukup menjadi

${ }^{12}$ Tungku merupakan tempat pembakaran batu sebelum menjadi batu kapur. Dalam pekerjaan pembakaran batu merupakan bagian dari buruh laki-laki, karena sangat tidak mungkin jika pekerjaan itu akan dilakukan oelh perempuan yang menjadi seorang ibu rumah tangga, yang seharusnya memiliki peran aktif dalam pekerjaan domestic atau pekerjaan internal keluarga. Karena dalam pembakaran batu tidak semudah membakar sampah, akan tetapi buruh harus siaga di depan pintu tungku dalam mempertahankan ketegangan api dalam tungku. Dimana buruh harus terus menerus memasukkan kayu kedalam tungku untuk menjaga api dalam tungku, agar hasil pembakaran batu tersebut lebih maksimal. Karena dalam pembakaran batu membutuhkan waktu satu hari satu malamatau 24 jam, sehingga sampai membuat buruh tidur di lokasi pembakaran atau didepan tungku. 
perhatian pemerintah. Karena mereka rela bekerja sebagai buruh batu kapur dengan waktu seharian, sedangkan pekerjaan primernya yang menjadi kwajibannya mengurus rumah tangga dan mengurus anakanaknya.

Pekerjaan memproduksi batu kapur di Desa Mangkung merupakan pekerjaan turuntemurun dari nenek moyang, sehingga dalam pekerjaan batu kapur memiliki metode dan aturan entah itu sudah dilakukan dari zaman dulu. Seperti dalam setiap satu tungku memiliki empat orang buruh, dan satu buru laki-laki dan tiga buruh perempuan. dimana dalam pekerjaan produksi batu kapur, juga memiliki pembagian kerja antara laki-laki dan perempuan, dimana laki-laki memiliki pekerjaan dari awal seperti membelah batu dengan menggunakan hamer sampai pembakaran batu sampai menjadi kapur, sedangkan perempuan bekerja dari pengeluaran batu kapur sampai pemasaran kapur. Akan tetapi disaat pemasaran kapur semua yang mengantar kapur ke tujuan pemasaran adalah buruh perempuan sampai 6 buruh bahkan lebih.

Bagi ibu rumah tangga diseluruh dunia, pekerjaan rumah tangga merupakan pekerjaan yang sangat penting, bahkan menjadi pekerjaan yang harus mereka utamakan. Sehingga menurut persepsi gender, itu merupakan aktivitas dimana perempuan itu harus mampu mencurahkan waktunya untuk mengurus anak-anaknya, dan mencurahkan komitmen bagi dirinya yang sangat berperan lebih aktif dari suaminya. Karena dengan memainkan peran mereka dengan pekerjaan di luar rumah, akan menjadikan perempuan sebenarnya mampu untuk memancarkan kualitas yang energik, karena memang mereka pada kenyataannya tidak akan mungkin hanya statis dari kwajiban dalam rumah tangga dan menunggu hasil materi dari suaminya. ${ }^{13}$

13 Cleves Mosse, Gender \& Pembangunan,. 38.
Oleh karena itu mereka juga mampu untuk melakukan pekerjaan dengan tujuan memberikan sedikit penghasilan walau dengan upah rendah, agar tidak membahayakan bagi pekerjaan dan kwajiban utamanya sebagai orang tua atau mengasuh anak-anaknya, karena yang sangat dominan dalam mengurus anak adalah si istri. Karena jikalau mereka hanya mengurus anak, mencuci, mengurus ternak, maka itu akan menurunkan substansi hidupnya atas ekonomi keluarganya. Oleh karena itu, pembagian kerja secara seksual mengandung sebuah makna dimana kaum perempuan dipandang sebagai pencari nafkah kedua setelah suaminya yang menjadi pencari nafkah pertama. Namun pertanyaannya apakah begitu fakta-fakta yang terjadi pada nasib kaum perempuan. karena jikalau semakin miskin atau rendahnya ekonomi keluarga, maka perempuanpun akan semakin sigap dalam pencarian nafkah dalam membantu ekonomi keluarganya. ${ }^{14}$

\section{Peran Ibu Rumah Tangga Sebagai Buruh Dalam Produksi Batu Kapur}

Berbicara tentang gender tentu akan mengkaji tentang tindakan kaum perempuan. oleh karena itu, gender merupakan konsep tentang bagaimana tindakan atau peran yang dilakukan oleh kaum perempuan dalam menunjukkan keseteraan dari kaum laki-laki, agar tidak selamnya dipandang rendah dari kaum laki-laki. Karena kadang peran dan tanggung jawabnya dalam struktur masyarakat kadang tidak adil, diakibatkan perempuan dipandang kaum yang lemah dari kaum lakilaki. ${ }^{15}$ Namun, jika hal ini kita sedikit menata dan menggubris perhatian kita terhadap, perjuangan kaum perempuan yang sudah menjadi ibu rumah tangga di sektor domestik, masih begitu tak sedikitpun merasa terbelenggu

14 Ibid,. 44-46.

${ }^{15}$ Ahmad Arif Syarif, Relasi Gender Suami Dan Istri (Skripsi, UIN Sunan Kalijaga Yogyakarta, 2016),. 12. 
dengan kondisinya yang dimana mereka memperjuangkan hak-haknya juga sebagai perempuan dalam sektor informal dengan menjadi buruh produksi batu kapur yang ada di Desa Mangkung.

Namun, pada konsep ketidakadilan gender, itu menunjukkan kekurangan atau kelemahan kaum perempuan. akan tetapi jika kita melihat fenomena yang terjadi terhadap para perempuan yang sudah menjadi ibu rumah tangga yang bekerja dengan menjadi seorang buruh produksi batu kapur di Desa Mangkung, akan menjadi sebuah wacana untuk menunjukkan kesetaraan dan relasi antara peran perempuan dengan laki-laki pada suatu tindakan pekerjaan yang dilakukan. Karena pada lingkup pekerja informal, kita bisa melihat kaum perempuan, baik yang kita temui banyak ibu-ibu rumah tangga yang lebih dominan ketimbang laki-laki. Misalnya ibu-ibu menjadi pedagang sayur, pedagang baju dan berpartisipai juga pada pekerjaan produksi petani, buruh kasar dan pekerjaan produksi lainnya. Oleh karena itu, didalam pekerjaan produksi batu kapur, ini bisa kita gunakan sebagai bentuk temuan dan wacana untuk menunjukkan kesetaraan dan relasi antara perempuan dan laki-laki, bahkan dalam produksi batu kapur ini memiliki buruh yang mayoritas perempuan dan mereka secara keseluruhan sudah menjadi seorang ibu rumah tangga.

Menurut Sofyan dan Zulkarnaen (2014) memaparkan lima bentuk ketidakadilan gender. Pertama, burden merupakan tindakan peran ganda dari kaum perempuan (istri) yang bekerja dalam mengurus pekerjaan rumah sangat dominan dari pada laki-laki (suami). Kedua, subordinat merupakan sebuah persepsi atau statement yang dimana perempuan itu harus berada dibawah laki-laki, misalnya didalam pendidikan, sosial, budaya, dan perpolitikan, atau yang biasa disebut dalam perspektif agama "Womens is the second of human" yang artinya wanita adalah manusia ke dua.
Ketiga, marginalisai merupakan proses dimana perempuan sedikit ditekan dalam tindakan pencarian nafkah untuk kebutuhan ekonomi, dan jarang untuk dilibatkan dalam pembentukkan kesejahteraan semata. Keempat, setereotype merupaka suatu persepsi atau statement yang dimana perempuan dianggap sebagai pencari nafkah kedua dari laki-laki, atau hanya menjadi penambah hasil ekonomi saja. Kelima, kekerasan terhadap perempuan (Violence) merupakan tindak kekerasan yang dilakukan oleh kaum laki-laki terhadap kaum perempuan.

Dalam pemaparan di atas jika saya menilik atas perjuangan para ibu rumah tangga di Desa Mangkung, tentu itu akan menjadi sedikit varian atas wacana tentang ketidakadilan gender. Karena perempuan di Desa Mangkung itu menjadi fenomena yang menarik dalam melakukan suatu tindakan pekerjaan yang sama dan setara dengan lakilaki. Mereka yang sudah menjadi seorang ibu rumah tangga, akan tetapi masih tetap eksis dalam pekerjaan produksi batu kapur yang dilakukan selain pekerjaan didalam rumah. Oleh karena itu beberapa perempuan di Desa Mangkung, mereka tidak hanya bekerja dalam mengurus rumah tangganya. Akan tetapi mereka juga ikut andil dalam pekerjaan dalam proses produksi batu kapur yang menjadi tempat untuk mendapatkan uang untuk membantu ekonomi keluarganya, dan tentu itu juga menjadi bentuk tindakan mereka dalam menunjukkan kesetaran dan relasi dengan kaum laki-laki.

Karena para perempuan yang sudah menjadi seorang ibu rumah tangga di Desa Mangkung, mereka sangat kolaborasi dalam pekerjaan produksi batu kapur tersebut. Dan itu menjadi suatu bentuk kesetaraan dan relasinya dengan kaum laki-laki, dan juga untuk melawan wacana ketidakadilan gender. Walaupun mereka sudah menjadi seorang ibu rumah tanggapun tidak begitu statis dan menunggu uang dari suaminya, akan tetapi 
mereka ikut bekerja keras dengan waktu yang cukup banyak yang mereka habiskan didalam pekerjaannya diluar rumah yakni menjadi buruh dalam produksi batu kapur. Dan mereka juga tidak merasa ditekan oleh pihak suami dan tidak juga terkendala akan adanya pekerjaan didalam rumah yang menjadi pekerjaan primernya. Seperti hasil dari wawancara peneliti dilapangan, dari sekian banyak buruh perempuan yang bekerja dalam proses produksi batu kapur, itu mereka semua sudah menjadi seorang ibu rumah tangga dan mereka sudah memiliki anak. Akan tetapi untuk menjaga keharmonisan keluarga dan pengertian satu sama lain, sebelum mereka berangkat bekerja ke lokasi pekerjaan sebagai buruh batu kapur, mereka sudah mempersiapkan kebutuhan suami dan anak-anaknya seperti sarapan dan lain sebagainya. Dan pada tindakan yang dilakukan oleh para ibu-ibu rumah tangga di Desa Mangkung, ini menjadi salah satu bentuk kesetaraan dan relasi kaum perempuan dengan laki-laki, karena mereka bekerja pada lingkup pekerjaan yang sama bahkan pekerjaan kaum perempuan lebih dominan sampai akhir yakni sampai pemasaran kapur. Bahwa kesetaran gender merupakan bentuk tindakan yang sama antara laki-laki dan perempuan, dimana suatu kesetaran itu menunjukkan suatu kontribusi dan partisipasinya secara bersama-sama dengan tujuan yang sama. ${ }^{16}$ Oleh karena itu didalam fenomena yang terjadi di Desa Mangkung, akan menjadi suatu bentuk kesetaraan antara laki-laki dan perempuan didalam sektor pekerjaan yang dilakukan seperti pada sektor produksi batu kapur. Dimana buruh kapur lakilaki maupun buruh perempuan memiliki pekerjaan yang serupa dan saling membantu satu sama lain. Walaupun secara eksistensi proses produksi batu kapur ini, menjadi

16 Siti Maemanah, DB. Paranaon, and Jamal Amin, "Implementasi Program Pemberdayaan Dalam Mewujudkan Kesetaraan Gender," Jurnal Administrative Reform, Vol 3 No 1, (March 2015). pekerjaan yang sulit dan memiliki proses yang lama untuk melihat hasil yang dilakukan oleh seorang buruh maupun pemiliki tungku. Akan tetapi, dalam proses produksi memiliki pekerjaan yang menjadi pekerjaan dan kwajiban sertiap buruh baik itu buruh laki-laki maupun buruh perempuan misalnya buruh laki-laki mendapatkan pekerjaan mulai dari pemecahan batu sampai pembakaran batu, sedangkan buruh perempuan mulai dari pengelurakan batu kapur setelah pembakaran sampai pemasaran kapur. Sehingga jika kita sedikit menyimak pada lingkup tindakan laki-laki dan perempuan pada proses produksi batu kapur, ini menjadi bentuk kesetaraan dan relasi antara laki-laki dan perempuan, karena mereka samasama memiliki tujuan yang sama dalam proses produksi batu kapur, sehingga mampu untuk membetuk kesetaraan dan relasi satu sama lain.

Oleh karena itu dalam proses produksi batu kapur juga mampu memberikan beberapa relasi antara buruh laki-laki dengan buruh perempuan seperti mulai dari penurunan batu dan kayu dari truk dan itu dilakukan oleh buruh laki-laki maupun buruh perempuan. Akan tetapi, pada tahap pemecahan batu itu hanya dilakukan oleh buruh laki-laki, karena itu menjadi pekerjaan yang tidak mungkin dilakukan oleh buruh perempuan yang sudah menjadi seorang ibu-ibu bahkan memiliki tenaga yang lemah dari pada laki-laki. Oleh karena itu pekerjaan buruh perempuan sudah ditetapkan oleh pemilik tungku dari pengeluran batu kapur setelah pembakaran sampai pemasaran. Namun ketika pembakaran batu, karena memiliki proses yang sangat lama satu hari satu malam, sehingga ketika buruh laki-laki mau istirahat oleh karena itu buruh perempuanpun ikut membantu pekerjaan lakilaki, dan ini menujukkan suatu kerja sama atau kolaborasi antara laki-laki dan perempuan dalam menunjukkan kesetraan dan relasi.

\begin{tabular}{|l|l|l|ll|}
\hline No & Nama & Usia & \multicolumn{2}{|l|}{ Pendidikan } \\
\hline 1 & Ibu Jaye & 44 Tahun & $\begin{array}{l}\text { Tidak } \\
\text { sekolah }\end{array}$ & pernah \\
\hline 2 & Ibu Adi & 46 Tahun & Tidak & pernah \\
\hline
\end{tabular}




\begin{tabular}{|l|l|l|l|}
\hline & & & sekolah \\
\hline 3 & Ibu Dian & 37 Tahun & Sekolah dasar \\
\hline 4 & Ibu Ita & 34 Tahun & $\begin{array}{l}\text { Tidak pernah } \\
\text { sekolah }\end{array}$ \\
\hline 5 & Ibu Lia & 35 Tahun & $\begin{array}{l}\text { Tidak pernah } \\
\text { sekolah }\end{array}$ \\
\hline 6 & Ibu Rendi & 35 Tahun & Sekolah dasar \\
\hline
\end{tabular}

Tabel 1: Nama-nama responden ibu rumah tangga yang bekerja sebagai buruh kapur Di Desa Mangkung

\section{Faktor Pendorong Ibu Rumah Tangga Bekerja Sebagai Buruh Dalam Produksi Batu Kapur}

Oleh karena itu kaum perempuan juga tidak akan selamanya statis dari tindakan menuju perubahan dan pembangunan. Karena perempuan juga mampu untuk bertindak partisipatif dalam hal pekerjaan diluar domestik. Di Desa Mangkung bagaimana semangat emansipatif perempuan yang sudah menjadi ibu-ibu rumah tangga, juga ikut melakukan tindakakn dalam pekerjaan yang sama dengan laki-laki pada pekerjaan produksi batu kapur. Entah itu didorong oleh budaya, motivasi atau alasan apapun, intinya mereka juga sama tindakannya dengan laki-laki dengan memancarkan bentuk kolaboratif dengan lakilaki dalam bidang pekerjaan informal seperti buruh produksi batu kapur. Karena pekerjaan dalam sektor informal merupakan suatu usaha yang dilakukan secara bebas oleh masyarakat, karena tidak dalam suatu lingkup kelembagaan pemerintah. Oleh karena itu sektor informal termasuk pekerjaan yang tidak resmi, atau menjadi tempat dimana masyarakat mendapatkan materi hanya untuk mendapatkan kebutuhan walaupun dengan pendapatan hasil yang tidak banyak.

Sektor informal sering dikaitkan dengan pekerjaan yang terutama berasal dari tenaga kerja keluarga tanpa besar penghasilan, usaha bahan baku yang melakukan eksploitasi atas memanfaatkan sumber daya alam, sebagian besar melayani kebutuhan rakyat kelas menengah ke bawah, dan biasaya yang menjadi pelaku dalam pekerjaan sektor informal ini merupakan orang dalam pendidikan dan kualitas sumber daya yang tergolong rendah. ${ }^{17}$ Sehingga dalam hal ini terhadap fenomena yang ada di Desa Mangkung, dimana masyarakatnya mampu untuk melakukan pengolahan sumber daya alamnya yang sedikit orang mengetahui eksistensinya yakni menjalankan proses produksi batu kapur. Sehingga dengan adanya semangat dan eksistensi ibu-ibu rumah tangga yang ikut andil bekerja sebagai buruh dalam proses produksi batu kapur, tentu didukung oleh beberapa factor pendorong atau penyebab mereka bekerja dengan menjadi buruh dalam produksi batu kapur yang mengikuti eksistensi dan partisipasi kaum laki-laki didalam sektor informal pada proses produksi batu kapur yakni;

\section{Membantu ekonomi keluarga}

Dalam setiap laki-laki dan perempuan yang membangun sebuah keluarga, tentu sangat mengidamkan kondisi keluarga yang nyaman dan tidak ada perdebatan. Akan tetapi, banyak keluarga yang mengalami perdebatan antara suami dan istri diakibatkan faktor ekonomi keluarganya yang rendah. Oleh karena itu, untuk mencukupi kebutuhan keluarga seperti beras, makanan, dan perabotan rumah tangga. ${ }^{18}$

Tentu itu berkunci pada faktor ekonomi keluarga itu sendiri. Sehingga sangat tidak mungkin jika hanya suami yang pergi mencari nafkah untuk membangun ekonomi keluarganya yang maksimal, walaupun suami yang pergi mencrai nafkah, sangat tidak mungkin perempuan hanya diam di rumah. Sehingga ibu rumah tangga di Desa Mangkung merupakan bentuk tindakan perempuan yang mencari nafkah pada sektor informal yakni pada buruh produksi batu kapur dengan

${ }^{17}$ Kuncoro Mudrajad, Ekonomi Pembangunan Teori, Masalah, Dan Kebijakan (Yogjakarta: Unit Penerbit dan Percetakan Akademi Manajemen Perusahaan YKPN, 2000),. 184.

18 Basrowi, Pengantar Sosiologi (Bogor: Ghalia Indonesia, 2005). 
berkolaboratif partisipatif dengan laki-laki. Dan itu menjadi alasan mereka bekerja sebagai buruh batu kapur, walaupun sudah menjadi ibu-ibu rumah tangga. Akan tetapi mereka mampu untuk membagi pekerjaan domestiknya walaupun lebih kebanyakan di luar rumah atau menjalankan aktivitasnya mengurus prosuksi batu kapur. Akan tetapi mereka sudah benar-benar mempersiapkan kebutuhan suami dan anaknya sebelum berangkat ke lokasi produksi. ${ }^{19}$

\section{Melestarikan Pekerjaan Budaya}

Para perempuan yang sudah menjadi seorang ibu rumah tangga di Desa Mangkung juga tetap eksis dalam pekerjaan yang sejatinya dilakoninya yang sudah bertahu-tahun, bahkan puluhan tahun yaitu sebagai buruh dalam produksi batu kapur. Melestarikan pekerjaan budaya maksudnya seperti pada penjelasan diatas, bahwa pekerjaan produksi batu kapur atau olahan batu menjadi sebuah kapur yang dimana kapur tersebut menjadi bahan atas suatu pembangunan misalnya rumah dan lain sebagainya, dan hal seperti itu sudah menjadi pekerjaan yang terimplikatif dalam pekerjaan budaya atau kultur, karena eksistensi produksi batu kapur di Desa Mangkung menjadi pekerjaan yang turun-temurun dari nenek moyang mereka. Oleh karena itu bagi masyarakat Desa Mangkung akan tetap konservatif dan melestarikan pekerjaan batu kapur ini. Dan pada dasarnya pekerjaan batu kapur ini, tentu akan dikerjakan oleh laki-laki maupun perempuan. Dan itulah yang menjadi alasan dan motivasi mereka dalam bekerja, walaupun mereka sudah menjadi seorang ibu rumah tangga. ${ }^{20}$

\section{Lemahnya Wawasan Dan Pemahaman}

Rendahnya pendidikan merupakan salah satu kendala para perempuan ibu rumah tangga kerja pada umumnya untuk masuk ke 2017.

${ }^{19}$ Wawancara Ibu Ita dan Ibu Dian, 23 Maret

${ }^{20}$ Wawancara Ibu Adi, 24 Maret 2017. pasar kerja yang berkualitas publik. Oleh karena itu mereka hanya bisa memasuki sektor informal yang tidak membutuhkan syarat pendidikan atau ijazah tertentu untuk menjadi bagian pekerja seperti dalam pekerja formal. ${ }^{21}$ Oleh karena itu, pendidikan menjadi peran yang sangat urgensi atau begitu sangat penting didalam kehidupan masyarakat, yang dimana baik buruknya kualitas sumberdaya manusia, itu juga sangat ditentukan dengan tinggi rendahnya tingkat pendidikan individu itu sendiri. Karena semakin tinggi tingkat pendidikan seseorang, maka semakin baik juga kualitas sumber daya manusianya. ${ }^{22}$ Akan tetapi dalam penelitian ini, bahwa para perempuan yang sudah menjadi ibu rumah tangga di Desa Mangkung secara keseluruhan itu memiliki tingkat pendidikan yang rendah bahkan sangat minim. Oleh karena itu, bagi mereka ini salah satu motivasi dan alasannya dalam menuangkan waktu dan juga tenaganya untuk bekerja dalam sektor produksi batu kapur, karena tentu bagi mereka yang memiliki pemahaman dan keterampilan yang sangat minim, dengan bekerja sebagai buruh batu kapur, tentu menjadi hal yang wajar baginya. ${ }^{23}$

\begin{tabular}{|c|c|c|}
\hline No & Jenis pekerjaan & $\begin{array}{l}\text { Curahan durasi } \\
\text { waktu pengerjaan }\end{array}$ \\
\hline 1 & $\begin{array}{l}\text { Mengeluarkan batu } \\
\text { kapur dari tungku } \\
\text { setelah pembakaran }\end{array}$ & 1-2 Hari \\
\hline 2 & $\begin{array}{lr}\text { Penyiraman } & \text { batu } \\
\text { kapur } & \text { setelah } \\
\text { pembakaran } & \end{array}$ & 1-2 Hari \\
\hline 3 & $\begin{array}{l}\text { Memasukkan dan } \\
\text { pengemasan kapur } \\
\text { ke dalam karung }\end{array}$ & 1-2 Hari \\
\hline 4 & Pemasaran kapur & Setengah hari \\
\hline
\end{tabular}

Tabel 2: jenis-jenis pekerjaan buruh perempuan pada produksi batu kapur

${ }^{21}$ M.Th. Handayani, "Karakteristik Dinamis Peran Ganda Pekerja Wanita Di Sektor Informal," Jurnal, ISSN : 0854-2813 Agrineca, Vol. 17 NO. I (January 2017), 15.

22 I Made Adi Wijaya and I G.A.P. Wirathi, "Faktor-Faktor Yang Mempengaruhi Pendapatan Ibu Rumah Tangga Yang Bekerja Pada Sektor Informal Di Kelurahan Dauh Puri Kauh, Denpasar Barat," E-Jurnal Ekonomi Pembangunan Universitas Udayana Vol. 2, No. 5 (Mei 2013),. 271.

${ }^{23}$ Wawancara Ibu Jaye, 23 Maret 2017. 


\section{Kendala Ibu Rumah Tangga Bekerja Sebagai Buruh Dalam Produksi Batu Kapur}

Kendala yang dirasakan oleh ibu rumah tangga yang bekerja didalam rumah maupun di luar rumah yakni memiliki dua jenis kendala yang dihadapi atau dirasakan ole ibu rumah tangga yang bekerja pada sektor informal atau bekerja diluar rumah yakni kendala (intern) dan kendala (extern). ${ }^{24}$ Oleh sebab itu, dalam setiap pekerjaan pasti memiliki suatu kendala yang dihadapi oleh para buruh baik itu perempuan maupun laki-laki, karena seperti halnya buruh perempuan yang sudah menjadi seorang ibu rumah tangga pada produksi batu kapur juga pasti akan merasakan kendala dalam menjalankan pekerjaannya, karena memang posisi mereka juga sama dengan para ibu rumah tangga yang lainnya yang menjalankan peran ganda.

Pertama, kendala (intern) yakni seperti lemahnya fisik dan lelah mental, karena menjadi seorang buruh pada produksi batu kapur memiliki pekerjaa yang berat dan prosesnya lama, bahkan pekerjaan yang didominasikan oleh buruh perempuan itu lebih banyak. Sehingga bagi mereka yang sudah menjadi seorang ibu rumah tangga akan sedikit kesulitan dan merasakan lelah terhadap klemahnya fisik yang dimilikinya dan juga membuat pekerjaannya menjadi sedikit lama dan molor. Misalnya dalam pekerjaan merubuhkan batu kapur setelah pembakaran itu akan menjadi pekerjaan yang membuat badan dan lengan mereka sakit dan pegal, karena mereka harus merubuhkan batu dari dalam tungku dengan menggunakan kayu dan cangkul dengan cara didorong agar batu kapur itu rubuh, setelah itu batu-batu kapur itu di bawa keluar untuk di siram dan digugurkan. Dan mereka juga bekerja dengan sampai tuntas

\footnotetext{
24 Ramadani, "Implikasi Peran Ganda Perempuan Dalam Kehidupan Keluarga Dan Lingkungan Masyarakat."
}

atau pada tahap akhir pada proses produksi batu kapur ini yakni sampai pemasaran kapur. Sehingga ini juga menjadi kendala secara fisik bagi mereka yang sudah menjadi seorang ibu rumah tanggga yang harus menaikan dan menurunkan kapur dari atas truk. Dan mereka ikut ke lokasi pemasaran sampai 8 buruh bahkan lebih ikut mengantarkan kapur ke lokasi pemasaran, dan ini juga menjadi kendala secara fisik, karena di lokasi produksi mereka turun naik truk dengan memikul kapur, setelah itu berangkat ke lokasi pemasaran dan sampai ke lokasi pemasaranpun begitu turunn naik truk dengan memikul kapur/karung. ${ }^{25}$

Akan tetapi, karena memiliki banyak kendala secara fisik dan membahayakan kesehatan bagi mereka sebagai seorang ibu rumah tangga yang bekerja sebagai buruh produksi batu kapur, sehingga mereka sudah mempersiapkan alat-alat untuk bekerja dalam menjaga kesehatan mereka disaat bekerja. Pertama, masker dengan tujuan agar tidak kena debu dan polusi kapur yang menyebabkan batuk dan filek. Kedua, sarung tangan dengan tujuan agar tangan mereka tidak kepanasan saat membawa kapur keluar dari dalam tungku setelah pembekaran, dan juga sebagai alat untuk menjaga kulit agar tidak tersirat oleh kapur, karena jikalau memegang kapur tanpa menggunakan sarung tangan, maka tangan mereka akan tersirat.

Kedua, kendala (extern) yakni sebelum mereka berangkat ke lokasi kerja sebagai buruh dalam produksi batu kapur, terlebih dahulu harus menjalankan perannya sebagai ibu rumah tangga dengan menjalankan tugasnya seperti memasak, mencuci, menyiapkan keperluan suami serta anak dan mengurus rumah tangga. Kemudian setelah itu mereka berangkat ke lokasi produksi batu kapur untuk bekerja dimulai dari pukul 7:00 pagi sampai dengan jam 5:00 sore. Sehingga kendala secara extern ini menunjukkan kendala pada internal

${ }^{25}$ Wawancara Ibu Rendi, 24 Maret 2017. 
keluarga mereka yaitu karena mereka berfikir dirinya sebagai ibu rumah tangga yang memiliki tanggung jawab penuh atas pekerjaan rumah, jadi mereka harus benar-benar menjaga keharmonisan keluarga, dan memenuhi tanggung jawabnya sebagai seorang ibu rumah tangga seperti menguruh kebutuhan suami dan anaknya. Akan tetapi ibu rumah tangga yuang bekerja sebagai buruh dalam produksi batu kapur. $^{26}$

\section{Kesimpulan}

Dalam penelitian ini membahas tentang peran ibu rumah tangga di Desa Mangkung, dan tindakan yang dilakukan oleh kaum perempuan yang sudah menjadi seorang ibu rumah tangga itu seperti berkolaborasi atau bekerjasama pada lingkup pekerjaan yang sama dengan kaum laki-laki. Seperti didalam pekerjaan sektor informal produksi batu kapur, antara laki-laki dan perempuan menjadi buruh yang memiliki tujuan yang sama dan bekerjasama pada produksi batu kapur, Karena dalam definisi kesetaraan merupakan bentuk tindakan yang memiliki tujuan yang sama antara kaum laki-laki dan kaum perempuan. Faktor pendorong atau penyebab ibu rumah tangga bekerja pada sektor informal pada proses produksi batu kapur yakni (a) memenuhi ekonomi keluarga, (b) melestarikan pekerjaan budaya, dan (c) lemahnya wawasan dan pemahaman. Dan tiga indikator ini cukup menjadi pendorong mereka yang sudah menjadi seorang ibu rumah tangga akan tetapi masih tetap eksis dalam pekerjaan produksi batu kapur. Dalam setiap pekerjaan yang dilakukan, setiap buruh atau pekerja memiliki kendala masing-masing misalnya kendala yang dihadapi buruh kapur terhadap mereka yang sudah menjadi seorang ibu rumah tangga di Desa Mangkung seperti memiliki fisik yang lemah sehingga membuat pekerjaan yang dilakukannya agak sedikit molor dan lama.

26Wawancara Ibu Lia, 24 Maret 2017
Kedua kendala secara tanggung jawab sebagai seorang ibu rumah tangga yang harus mampu memenuhi kwajibannya di dalam mengurus rumah tangga sebelum memenuhi kwajibannya di dalam lokasi pekerjaan.

\section{Daftar Kepustakaan}

A. P, Sofyan, and Zulkarnaen Suleman. Fikih Feminis Menghadirkan Teks Tandingan. Yogyakarta: Pustaka Pelajar, 2014.

Ardianto, Elvinaro. Metodologi Penelitian Untuk Publik Relations Kuantitatif Dan Kualitatif (. Bandung: Simbiosa Media, 2010.

Arisandi, Herman. Buku Pintar Tokoh-Tokoh Sosiologi Dari Klasike Sampai Modern. Yogyakarta: IRCiSoD, 2015.

Basrowi. Pengantar Sosiologi. Bogor: Ghalia Indonesia, 2005.

Cleves Mosse, Julia. Gender \& Pembangunan. Yogyakarta: Rifka Annisa Women's Crisis Center, 2018.

Mudrajad, Kuncoro. Ekonomi Pembangunan Teori, Masalah, Dan Kebijakan. Yogjakarta: Unit Penerbit dan Percetakan Akademi Manajemen Perusahaan YKPN, 2000.

\section{Jurnal ilmiah}

Adi Wijaya, I Made, and I G.A.P. Wirathi. "Faktor-Faktor Yang Mempengaruhi Pendapatan Ibu Rumah Tangga Yang Bekerja Pada Sektor Informal Di Kelurahan Dauh Puri Kauh, Denpasar Barat." E-Jurnal Ekonomi Pembangunan Universitas Udayana Vol. 2, No. 5 (Mei 2013).

Handayani, M.Th. "Karakteristik Dinamis Peran Ganda Pekerja Wanita Di Sektor Informal." Jurnal, ISSN: 0854-2813 Agrineca, VOL. 17 NO. I (January 2017).

Maemanah, Siti, DB. Paranaon, and Jamal Amin. "Implementasi Program Pemberdayaan Dalam Mewujudkan Kesetaraan Gender." Jurnal Administrative Reform, Vol 3 No 1, (March 2015).

Pariyanti, Eka. "Peran Ibu Rumah Tangga Dalam Meningkatkan Pendapatan Keluarga." Jurnal DINAMIKA Vol. 3 No. 2 (Desember 2017). 
Ramadani, Ninin. "Implikasi Peran Ganda Perempuan Dalam Kehidupan Keluarga Dan Lingkungan Masyarakat." Sosietas Vol. 6 No. 2 (September 2016).

Tuwu, Darmin. "Peran Pekerja Perempuan Dalam Memenuhi Ekonomi Keluarga: Dari Peran Domestik Menuju Sektor Publik." Jurnal Al Irzab: Jurnal Hasil-Hasil Penelitian-ISSN: $1978-9726$ (p); 2541-0717 (e) Volume 13, Nomor 1 (Mei 2018).

\section{Skripsi}

Arif Syarif, Ahmad. Relasi Gender Suami Dan Istri. Skripsi, UIN Sunan Kalijaga Yogyakarta, 2016.

Firdiansyah R, M. Arnas. "Pengaruh Motivasi

Bekerja Perempuan Di Sektor Informal Terhadap Pembagian Kerja Dan Pengambilan Keputusan Dalam Keluarga." Skripsi Institut Pertanian Bogor, 2009.

\section{Wawancara}

Observasi 22 maret 2017

Wawancara pemilik tungku 22 maret 2017

Wawancara ibu ita 23 maret 2017

Wawancara ibu dian 23 maret 2017

Wawancara ibu jaye 23 maret 2017

Wawancara ibu rendi 24 maret 2017

Wawancara ibu lia 24 maret 2017 